\title{
IMPACT OF THE LEVEL OF DIGITAL PUBLIC SERVICES ON THE FULFILLMENT OF TAX OBLIGATIONS
}

\author{
Denisa Ihnatišinová ${ }^{1}$
}

Received: June 29, 2021 / Revised: September 15, 2021 / Accepted: November 2, 2021

(C) Association of Economists and Managers of the Balkans, 2021

\begin{abstract}
The purpose of the paper is to find out how digitalization makes it possible to simplify the fulfilment of tax obligations of taxable persons - entrepreneurs. Digital development of tax administration means the level of digital services to tax entities. Taxpayers are perceived by the tax administration as clients who need to be simplified as much as possible. Introducing or increasing the provision of online services, pre-filled forms or electronization of invoices are current trends that reduce the time devoted to taxes. By monitoring the relationship between the development of the level of digital public services and the evolution of the number of hours needed to meet the tax obligations of the entrepreneur, it was found that the gradual introduction of digital projects reduces the administrative burden on taxable persons.
\end{abstract}

Keywords: Digitalization, Tax, Digital project, Technology.

\section{JEL Classification H25}

denisa.ihnatisinova@euba.sk 


\section{INTRODUCTION}

The tax obligations of entrepreneurs mean not only the payment of taxes, but also the fulfilment of obligations related to registration with the tax administrator, notification of certain information or changes to the tax administrator, filling in and translating tax returns and other tax documents, or carrying out tax control. All these processes represent an administrative burden for the entrepreneur, which is associated with the payment of taxes during the business activity.

The level of digital public services intended for taxpayers affects their burden of bureaucracy and administration in fulfilling their tax obligations. The increasing level of digitalization has resulted in the simplification of the life situations of taxpayers. The low level of digital skills of taxable persons in relation to the provision of new products using the latest information technologies may be a weakness in the expansion of digitalization.

The improvement of the quality of services to tax entities is realized through a change in processes that have been carried out on paper and manually on digitized processes. Data are shared between the State and other public and private sector bodies, so-called third parties. Developments in the digitalization of tax administrations can be summarised as follows: (OECD, 2020, p. 10)

1. The introduction of better-verified reporting through third parties (e.g. integration of information into administrative processes originating from financial intermediaries, other parts of government, other taxpayers and other tax administrations);

2. The adoption of more reliable reporting systems (e.g. digitisation of VAT invoices, online cash registers, incorporation of basic tax rules into accounting software, etc.);

3. Better identification of possible non-compliance through better risk assessment modelling, the use of increasing digital data and advanced analytical techniques;

4. Improvements to services for taxpayers, including through electronic filing, pre-filled filing data, electronic payments, online self-service tools and targeted assistance such as online live chats. This makes it easier for taxpayers to understand and fulfil their obligations.

The research question arises whether digitising processes and services simplify the fulfilment of tax obligations of entrepreneurs. Quality digital services by the State depends on the digital performance of the economy as a whole. This premise further questions whether digitally the best performing countries provide high-level digital public services.

\section{RESEARCH BACKGROUND - DIGITAL PERFORMANCE WITH A FOCUS ON DIGITAL PUBLIC SERVICES IN EU COUNTRIES}

According to the Digital Single Market Strategy for Europe (EC, 2015), the digital single market will ensure that Europe maintains its global leadership in the digital economy. The EU's positive approach to digital transformation is based on the need to adapt to the digital age. The Digital Single Market opens up new opportunities as it closes the gap between the online and offline worlds and removes barriers to cross-border online activity. The efficiency of creating a digital single market in the EU is examined mainly from an economic point of view.

The digitalization of the economy has a predominantly positive impact on the socio-economic development of individual regions and countries and the digitalization of public services benefits the recipients of these services (Agostino et al., 2021) and affects their satisfaction and confidence (Krotel, 2021); but, on the other hand, the threat arising from digitalization is the emergence of obstacles preventing certain social groups from accessing and using technology correctly (Kwi- 
linski et al., 2020). Research papers confirm the existence of a digital divide and uneven development of digital competencies (van Dijk, 2009; Cruz-Jesus et al., 2012; Caradaica, 2020). The implementation of new information technologies in the public sector, mandatory digital service delivery strategies, where users are forced to access the service through a digital channel and insufficient digital skills of employees are actual research areas (Pedrosa et al., 2020; Gholami et al., 2021; Tangi et al., 2021).

The relationship between digitalization and the fulfilment of tax obligations is currently not examined in detail. Therefore, the research question will be outlined as to whether a higher digital performance of public services will make it easier to meet tax obligations and thus increase the collection of tax revenues. Other consequences of simplifying tax obligations may be reflected in the promotion of business activities. During the business lifecycle, the tax burden varies from strongly negative to insignificant. The most significant negative effects will be felt in the early stages of the business. The authors (Braunerhjelm et al., 2019) concluded that a $10 \%$ reduction in the tax administrative burden increases the susceptibility to the emergence of a new enterprise by $4 \%$. These are certainly behind the idea that simplifying tax obligations is one way to boost entrepreneurship. The burden imposed by tax laws and compliance with tax regulations constitutes an obstacle to entry into business (Braunerhjelm, Ecklund, 2014).

The EU is made up of countries that are economically or demographically different, divergent in their approach to public policies, thus creating an uneven development of digital competencies, and a single digital market is fragmented. The creation of a single digital market, therefore, depends heavily on meeting the commitments of EU countries to implement key digital initiatives. The digital maturity of EU countries is diverse and cannot be derived from the country's economic maturity. This means, for example, that the most economically powerful country does not automatically mean that it is also digitally the most powerful. Consequently, it is necessary to examine the performance and development of sub-areas of digital transformation. In order to optimise public sector processes, the introduction of proactive so-called intelligent electronic services by the State is linked. It is the area of digitalization of public services that is crucial and the EU is monitoring and evaluating developments in the provision of eGov services to states. We can see these digital performance relationships of EU countries compared to the EU-28 average in Figure 1.

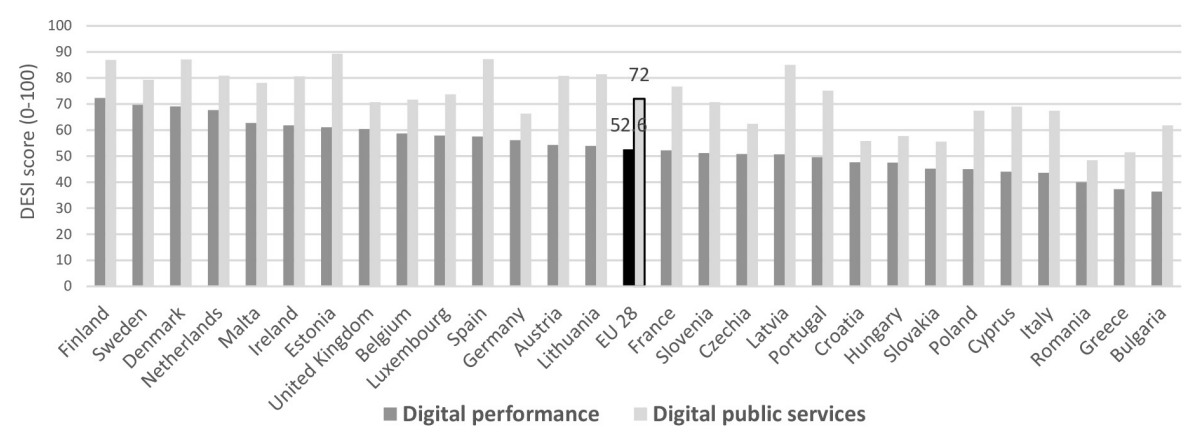

Figure 1. Digital performance in EU countries

Source: Own processing according to The Digital Economy and Society Index (DESI 2020)

The digital performance of EU countries is diverse, with the EU-28 average at a score of 52.6. Exactly half of the EU countries are digitally powerful above the EU average (scores 53.9 to 72.3 ) and the other half are digitally powerful below the EU average (scores of 36.4 to 52.6). Finland, 
Sweden, Denmark and the Netherlands are the countries using the most advanced digital technologies. Even the largest EU economies in terms of GDP - Ireland and Luxembourg are not among the pioneers in digitalization, which has a significant impact on the overall performance of the Single Market. For example, countries such as Malta, Estonia and Lithuania, whose size is below the EU-28 average, are above the EU average for digital performance. Slovakia, as a country of below-average economic maturity, is also a country with below-average digital performance.

It is economically advanced countries that are lagging in the digitalization of the economy, e.g. Germany, Italy or France. There are introducing targeted investments in all areas of digitalization, i.e. in order to make progress in digitalization initiatives aimed at IT security, supercomputers and artificial intelligence, to facilitate the digitalization of public services and, last but not least, to implement the strategies that put digitalization and innovation in the spotlight and through which the digital transformation of the country is taking place (EC, 2020). The practical implementation of the developed digital market transition strategy will make it possible to manage emerging threats more effectively towards digitalization and to make optimal use of development opportunities. That strategy is also applicable to the public sector, business sector and individual households (Yanina et al., 2021).

Figure 1 shows that electronic public administrations operate effectively in Estonia, Spain, Denmark and Finland, all with scores above 85. Half of the Member States are below the EU rate of 72, but a score of less than 60 is achieved by Croatia, Slovakia, Greece and Romania. In this context, digital performance as a whole and performance only in the area of public services need to be distinguished. While Finland, Sweden and Denmark have been identified as leaders in the overall digitalization of the economy, Estonia, Spain and Denmark lead the way in digitising public services. A more detailed overview of parts of digital public services is provided in Table 1.

Table 1. Components of digital public services in the EU (the first three and last three countries)

\begin{tabular}{|c|c|c|c|c|c|}
\cline { 2 - 6 } \multicolumn{1}{c|}{} & $\begin{array}{c}\text { eGovernment } \\
\text { users }\end{array}$ & $\begin{array}{c}\text { Prefilled } \\
\text { forms }\end{array}$ & $\begin{array}{c}\text { Online service } \\
\text { completion }\end{array}$ & $\begin{array}{c}\text { Digital public } \\
\text { services for } \\
\text { businesses }\end{array}$ & $\begin{array}{c}\text { Open } \\
\text { Data }\end{array}$ \\
\hline Top & $\begin{array}{c}\text { Finland, Estonia, } \\
\text { Denmark }\end{array}$ & $\begin{array}{c}\text { Malta, Estonia, } \\
\text { Lithuania }\end{array}$ & $\begin{array}{c}\text { Malta, Portugal, } \\
\text { Denmark }\end{array}$ & $\begin{array}{c}\text { Estonia, Denmark, } \\
\text { Luxembourg }\end{array}$ & $\begin{array}{c}\text { Ireland, Spain, } \\
\text { France }\end{array}$ \\
\hline Down & $\begin{array}{c}\text { Italy, Greece, } \\
\text { Germany }\end{array}$ & $\begin{array}{c}\text { Romania, United } \\
\text { Kingdom, Greece }\end{array}$ & $\begin{array}{c}\text { Romania, Croatia, } \\
\text { Cyprus }\end{array}$ & $\begin{array}{c}\text { Romania, Greece, } \\
\text { Croatia }\end{array}$ & $\begin{array}{c}\text { Hungary, } \\
\text { Slovakia, Malta }\end{array}$ \\
\hline
\end{tabular}

Source: Own processing according to the DESI

The disparity in the digital performance of public administration within the EU is large and they alternate between the first and last places of the country when analysing the five-part eGov indicator. However, the result from the digital public service dimension is confirmed, i.e. Estonia and Denmark are the leading eGov leader, and Greece and Romania are the weakest eGov countries, as they are most common in all five eGov areas.

The growing share of the digital economy in GDP is due not only to the digitalization of the private sector but also to the public sector, which includes tax administration. The priority task of the tax administration is to ensure the implementation of the revenue part of the state budget as well as the EU budget. The key task of the tax administration is thus to effectively collect tax revenues to meet the statutory amount of revenue, monitor the fulfilment of revenues and take measures to achieve their fulfilment. Digital leaders in the transition from paper tax administration to electronic are characterized by a high number of digital projects in the tax administration 
environment. New tools for communication of tax administration with tax entities are introduced by digitalizing information in the collection and payment of taxes. Tools such as digital assistants and chatbots come to the foreground, that is in absolute terms used the least, but the year-on-year percentage increase in usage has been highest (Ihnatišinová, 2021a). At the same time, the digitalization of processes in the tax administration environment is a tool to simplify the fulfilment of tax obligations by tax entities (Ihnatišinová, 2021b). These are greatly facilitated by the payment of taxes, and the introduction of new technologies in the tax administration environment poses a major challenge for many countries (PwC and World Bank Group, 2019).

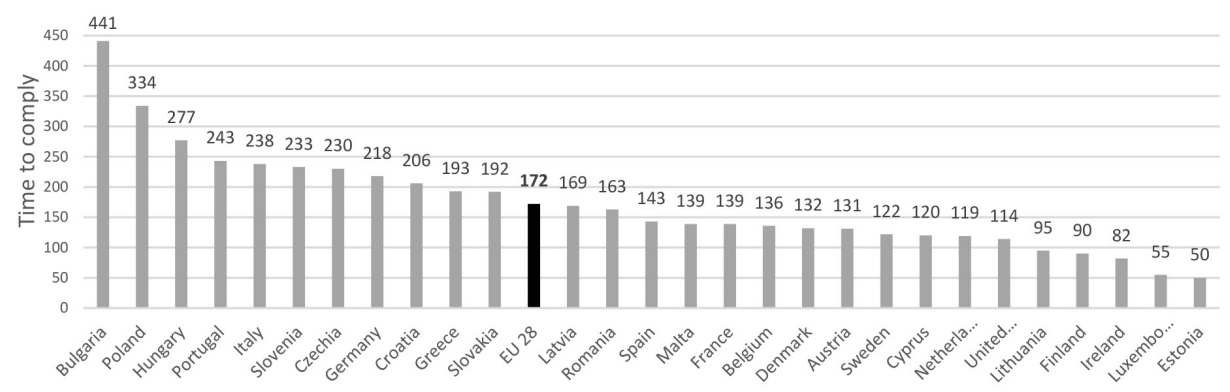

Figure 2. Time to comply with taxes in EU countries

Source: Own processing according to the Paying Taxes 2020

Figure 2 shows that the number of hours that entrepreneurs need to meet their tax obligations across the EU ranges from 50 hours in Estonia to 441 hours in Bulgaria. Most EU countries are below the EU-28 average of 172 hours. Ireland, Denmark, Finland are at the top of the world in terms of the use of digital public services in the tax administration environment, and in the second ten, it is Estonia, Lithuania, Latvia. In Estonia, entrepreneurs only need 50 hours to meet their tax obligations, well below the EU average. In Slovakia, it is up to 192 hours.

\section{METHODOLOGY}

The examination of the impact of overall digital performance on the level of the state's digital public services and/or electronic services is based on the fact that digitally performing economies also provide high-level digital public services. Consequently, the examination of the impact of the digital performance of public services on the fulfilment of tax obligations is based on the assumption that a high level of digital public services will be reflected in a better and easier fulfilment of tax obligations by taxable persons - entrepreneurs, i.e. in a lower number of hours associated with the administration of taxes.

Inconsistency with the main aim and the research questions the hypotheses to be tested are formulated as below:

H1: The higher the digital performance, the higher the level of digital public services;

H2: The higher the level of digital public services makes it easier to pay taxes.

To test the hypotheses of the research is used the statistical independence analysis to assess the dependence between the two variables. The digital performance of the economy is expressed by the overall score of the DESI index, the digital performance of public services is expressed by the overall score of the digital public service dimension of the DESI index, and the ease of paying tax- 
es is expressed by the number of hours needed to meet the tax obligations of entrepreneurs. The data are drawn from Eurostat, the European Commission, PwC and the World Bank. The review period is 2019 and the UK is also assessed as an EU country.

\section{RESULTS AND DISCUSSION}

Hypothesis 1 that the level of digital public services is also increasing as digital performance grows has been confirmed, with the dependence between overall digitalization and digitalization of public services being weaker in the digital best-performing countries and stronger in digitally less powerful countries. The results are documented in Figure 3.

The relationship between overall digital performance and the level of digital public services is directly linearly dependent, with a very high correlation coefficient of 0.75 , i.e. the level of digitalization increases, the level of digital public services also increases. However, if we examine this relationship only within the digitally performing countries, the results are slightly different. This means that of the 14 countries above the EU-28 average in the overall digitalization of the economy and society, 11 countries are digitally powerful, including the area of digital public services, and 3 countries are below the EU average for digital public services. In this case, there was a weak positive correlation with a correlation coefficient of 0.38 .

An examination of the relationship between overall digitalization and digitalization in public services in countries that are less digitally efficient shows that out of 14 countries there are 3 countries that, despite the lower overall digital performance, achieve above-average values in digital public services. 11 countries with below-average overall digitalization also achieve below-average to low levels in digital public services. In this case, there was a large positive correlation with a correlation coefficient of 0.62 .

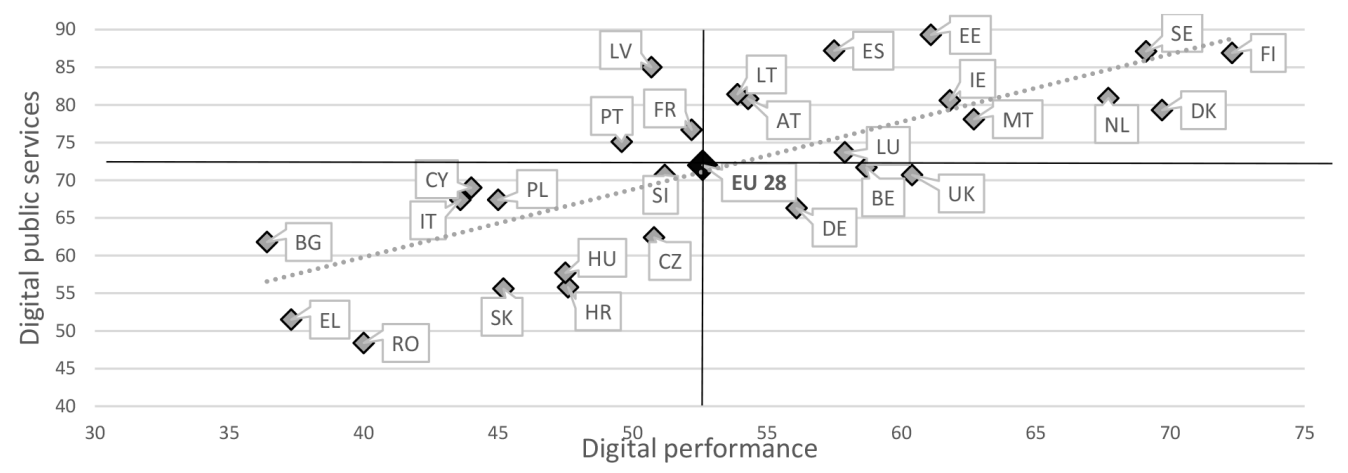

Figure 3. Relationship between digital performance and level of eGov in EU countries

Source: Own processing

Hypothesis 2 has been confirmed since the correlation coefficient is $-0,54$. There is an indirect relationship between the level of digital public services and the number of hours to meet tax obligations within the EU, but we can only describe it as moderate. This may be since the state's electronic services are provided in different public areas and digital projects in the tax administration spotlight are only one part of all digital projects throughout the public administration. Nevertheless, the negative relationship between eGov and the ease of paying taxes exists, as documented in Figure 4. 


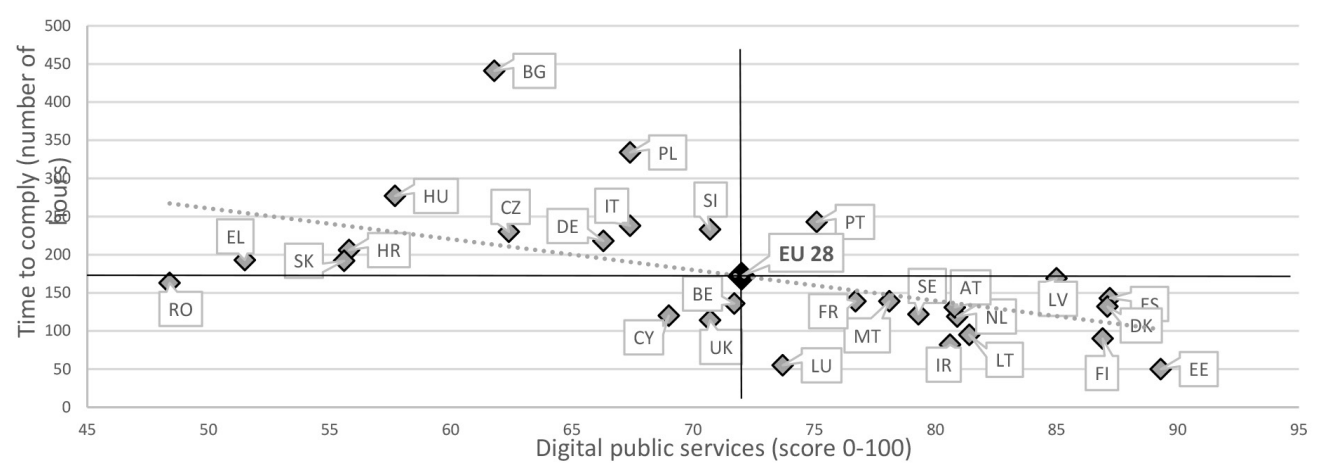

Figure 4. Relationship between level of eGov and time to comply with taxes in EU countries

\section{Source: Own processing}

Of the 14 countries that are above average in the provision of state electronic services, up to 13 countries can be identified as with a simple tax system because the number of hours to meet tax obligations is below the EU average, i.e. between 55 hours and 169 hours. However, the correlation coefficient, in this case, is -0.24 , which confirms a very weak negative correlation between variables. The variation range for the number of hours to meet tax obligations is 114 hours in countries with above-average digital public services.

Of the 14 countries with a level of digital public services below the EU average, up to 10 countries do not have a simple tax administration system and thus the fulfilment of tax obligations by entrepreneurs is complicated because it takes between 192 hours and 441 hours. The correlation coefficient, in this case, is -0.06 , which confirms too weak or zero correlation between variables. The variation range for the number of hours to meet tax obligations is up to 249 hours in countries with below-average digital public services. This means that these countries have huge scope to implement digital projects in a tax administration environment.

On 9 March 2021, the Commission presented a vision and ways to achieve Europe's digital transformation by 2030. This vision of the EU digital decade focuses on four fundamental areas: skills, the digital transformation of businesses, secure and sustainable digital infrastructures and the digitalisation of public services. Digital public services should include key public services: 100\% online, eHealth: $100 \%$ availability of health records and digital identity: $80 \%$ of citizens using digital ID cards (EC, 2021).

From results of the paper follows a recommendation for Slovakia to modernise the tax administration system with a focus on digitalization, based on the provision of quality state electronic services throughout public administration. According to the Strategy to Improve the Position of the Slovak Republic in the DESI index until 2025, the vision is that: „Slovakia will actively develop digital trends over the next five years and, thanks to innovation, improve the lives of its citizens, conditions for entrepreneurship and make the most of the full potential that digitalization provides across the economy and society." If the Slovak Republic improves its overall digital performance, it will also increase the level of digital public services and consequently simplify the administration of taxes. The implementation of digital projects in the tax administration environment is crucial. Slovakia has been applying a dual model of public administration since 1990, based on which there is a separate existence of state administration and self-government (Belkovicsová et al., 2020); particular attention should be paid to the development of digitalization at the municipal level. Entrepreneurs, as tax taxpayers of local taxes, also fulfil their tax obligations towards municipalities that are local tax administrators. 


\section{CONCLUSION}

The importance of digitalization for the fulfilment of tax obligations depends on the level of digital public services, which are one of the dimensions of overall digital performance. The state's electronic services, which are well implemented, allow citizens, businesses and organisations to interact with the government more easily, faster and at a lower cost. The digitalization of public services brings transparency and openness to governance. The results of the article show that the level of digital public services is also increasing as overall digital performance increases, while in the digitally performing countries the dependence between overall digitalization and digitalization of public services is weaker, and in digital less powerful countries this dependency is stronger.

In fulfilling tax obligations, the importance of digitalization lies in reducing the administrative burden on entities. The inversely proportional relationship between digitalization and tax administration has been confirmed, i.e. increasing the level of digital public services simplifies the fulfilment of tax obligations and reduces the number of hours associated with paying tax within EU countries.

Looking at more and less digitally efficient countries in the field of public services, it is necessary to take into account the types of digital projects implemented in the tax administration environment. The results of the article show that as digital performance in public services grows, the number of hours needed to meet tax obligations decreases, while in digitally more powerful countries the dependence between the digitalization of public services and the ease of paying taxes is weaker, and in digitally less powerful countries this dependency is almost zero. Therefore, less developed countries should be able to implement reforms that reduce the cost of paying taxes. The most popular digital reforms are the introduction or expansion of the online system for paying taxes, the use of electronic registration and payment systems, the transition from the manual filing of tax returns to the electronic filing of tax returns. Other digital initiatives that simplify the fulfilment of tax obligations are pre-filled tax returns by the tax administration, which reduce preparation time for taxpayers or mandatory electronic invoicing.

\section{ACKNOWLEDGMENT}

This paper is an output of the research project supported by the Grant Agency of the Ministry of Education of the Slovak Republic and the Slovak Academy of Sciences (VEGA) No. 1/0779/19 Výzvy digitalizácie ekonomiky pre oblast' zdaňovania, možné riě̌enia a ich predpoklady (Challenges of digitalisation of the economy for taxation, possible solutions and their assumptions). 


\section{REFERENCES}

Agostino, D., Arnaboldi, M., \& Lema, M.D. (2021). New development: COVID-19 as an accelerator of digital transformation in public service delivery. Public Money \& Management 41(1), 69-72. doi:10.1080/09540962.2020.1764206

Belkovicsová, D., Bukovová, S., \& Staríčková, Z. (2020). Aktuálne ekonomicko-finančné problémy domácností SR v súčasnej globalizovanej ekonomike. Bratislava: Vydavatel'stvo EKONÓM.

Braunerhjelm, P., \& Eklund, J. E. (2014). Taxes, tax administrative burdens and new firm formation. Kyklos 67, 1-11. https://doi.org/10.1111/kykl.12040

Braunerhjelm, P., Eklund, J., \& Thulin, P. (2019). Taxes, the tax administrative burden and the entrepreneurial life cycle. Small Business Economics 56, 681-694 http://dx.doi.org/10.1007/ s11187-019-00195-0 .

Caradaica, M. (2020). Digital Divide in the European Union. In Proceedings of 7th ACADEMOS Conference 2020 International Conference "Politics and Knowledge: New Trends in Social Research", Faculty of Political Science, National University of Political Studies and Public Administration, Bucharest, Romania, 7-10 October 2020.

Cruz-Jesus, F., Oliveira, T., \& Bacao, F. (2012). Digital divide across the European Union. Information \& Management 49, 278-291. https://doi.org/10.1016/j.im.2012.09.003_

European Commission. (2015). A Digital Single Market Strategy for Europe - COM(2015) 192 final. Retrieved from EUR-Lex - 52015DC0192 - EN - EUR-Lex (europa.eu)

European Commission. (2020). Digital Economy and Society Index (DESI) 2020. Thematic chapters. Retrieved from https://innogrowth.org/wp-content/uploads/2020/07/DESI-2020.pdf

European Commission. (2021). 2030 Digital Compass: The European way for the Digital Decade. $\operatorname{COM}(2021)$ 118. Retrieved from: https://eur-lex.europa.eu/legal-content/en/TXT/?uri=CELEX\%3A52021DC0118

Gholami, R., Singh, N., Agrawal, P., Espinosa, K., \& Bamufleh, D. (2021). Information Technology/ Systems Adoption in the Public Sector. Journal of Global Information Management 29(4), 172-194. doi:10.4018/jgim.20210701.oa8

Ihnatišinová, D. (2021a). Digitalization of tax administration communication under the effect of global megatrends of the digital age. In SHS Web of Conferences 92, 02022 The 20th International Scientific Conference Globalization and its Socio-Economic Consequences 2020 University of Zilina, Faculty of Operation and Economics of Transport and Communications,

Department of Economics, Slovak Republic, Rajecke Teplice, 21.-22. October 2020. https://doi.org/10.1051/shsconf/20219202022

Ihnatišinová, D. (2021b). Increasing the Level of Digital Development of Tax Administration in Slovakia. In Finansovi instrumenty staloho rozvytku ekonomiky: 3. mižnarodna naukovo-praktyčna konferencija $=3$. International Scientific and Practical Conference, Černivci: Černivec`kyj nacional'nyj universytet, 2021 (pp. 13-16.)

Krotel, S. ML. (2021). Digital Communication of Public Service Information and its Effect on Citizens' Perception of Received Information. International Journal of Public Administration 44(2), 132-145. https://doi.org/10.1080/01900692.2019.1672182

Kwilinski, A., Vyshnevskyi, O., \& Dzwigol, H. (2020). Digitalization of the EU Economies and People at Risk of Poverty or Social Exclusion. Journal of Risk and Financial Management 13(7), 142. https://doi.org/10.3390/jrfm13070142

Ministry of Investments, Regional Development and Informatization of the Slovak Republic. (2020). Strategy and action plan to improve Slovakia's position in the DESI index by 2025.

OECD. (2020). Tax administration 3.0. The Digital Transformation of Tax Administration. OECD Publishing, Paris. Retrieved from Tax Administration 3.0: The Digital Transformation of Tax Administration (oecd.org) 
Pedrosa, G.V., Kosloski, R.A.D., Menezes, V.G.d., Iwama, G.Y., Silva, W.C.M.P.d., \& Figueiredo, R.M.d.C. (2020). A Systematic Review of Indicators for Evaluating the Effectiveness of Digital Public Services. Information, 11(10), 472. https://doi.org/10.3390/info11100472

PwC, World Bank Group. (2019). Paying Taxes 2020. Retrieved from https://www.pwc.com/gx/en/ paying-taxes/pdf/pwc-paying-taxes-2020.pdf

Tangi, L., Benedetti, M., Gastaldi, L., Noci, G., \& Russo, C. (2021). Mandatory provisioning of digital public services as a feasible service delivery strategy: Evidence from Italian local governments. Government Information Quarterly 38(1), 101543. https://doi.org/10.1016/j. giq. 2020.101543

Van Dijk, Jan A.G.M., (2009). The Digital Divide in Europe. In The Routledge Handbook of Internet Politics. Ed. Andrew Chadwick and Philip N. Howard, 2008, Routledge Handbooks Online.

Yanina O, Loktionova Y, Pugacheva E, Bokov Y, \& Zatsarinnaya E. (2021). Formation and Implementation of a 'Digital Single Market' Concept in the Context of Digital Economy Expansion. Global Business Review. https://doi.org/10.1177/09721509211010028_ 